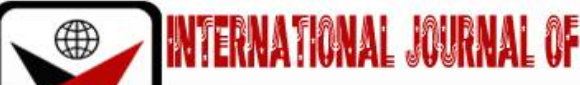

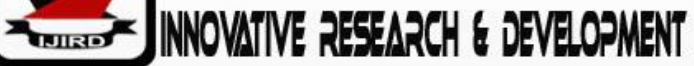

ISSN 2278-0211 (Online)

\section{Impediments to and Optimized Measures for Implementing Universal Upper Basic Education Programme through Prevocational Education for Quality Assurance in Nigeria}

\begin{tabular}{c}
\hline Dr. Jane Itohan Oviawe \\
Senior Lecturer, Department of Vocational and Technical Education \\
Ambrose Alli University, Ekpoma, Edo State, Nigeria \\
Raymond Uwameiye \\
Professor, Department of Vocational and Technical Education \\
Ambrose Alli University, Ekpoma, Edo State, Nigeria
\end{tabular}

\section{Abstract:}

The Universal Basic Education (UBE) policy in conception and disposition is capable of transforming Nigeria positively if properly implemented. UBE will enable Nigerian students and teachers to adjust and adapt to complex and dynamic social, scientific and technological changes that would create a new Nigeria. However, one thing is to create policies and another is to implement and execute it. The implementation of the programme has however faced a number of impediments that have affected its effectiveness. It is against this background that this paper looked at the objectives of the UBE programme and issues of implementing the UBE programme through prevocational education. This paper also looked at prevocational education in Nigeria and suggested the quality assurance measures for implementing UBE programme through prevocational education among which are providing proper funding, recruitment of qualified teachers, provision of instructional materials and adequate planning.

Keywords: Impediments, strategies, universal basic education, prevocational education, quality assurance

\section{Introduction}

Education is a systematic process through which an individual acquires knowledge, experiences and skills. It is one of the vital instruments for development. According to the Federal Republic of Nigeria (FRN) (2013), education is an instrument 'per excellence' for affecting national development. Certainly, what Nigeria as a developing country needs now to turn her economy around is a basic education programme that will ensure that every Nigerian youth on graduation is sufficiently equipped with knowledge, basic skills and experiences through exploration in the ever-dynamic world of work. Realizing the importance of basic education, successive governments in Nigeria have emphasized it as an instrument that will help government to realize its educational goals. In this realization that all successive governments since 1976 have been emphasizing basic education.

Basic education is the foundation of education for sustainable life-long learning. It began during the colonial era by providing reading, writing and arithmetic (numeracy) skills to enable the learners to acquire functional literacy. Since independence in 1960, several of educational policies, laws and reforms have been in place depending on the government of the day. Ajayi and Adeyemi (2011) asserted that Nigerian education policies are characterized by a high level of uncertainties. This is because education system is dynamic and has witnessed a lot of changes in policies and programmes. The FRN in 1977 put in place a key policy which originated from the 1973 seminar, which held after the 1969 national curriculum conference held in Lagos and named National Policy on Education. This 1977 policy has been revised four times (in 1981, 1998, 2004 and 2013). Since then 1977, the FRN in its national policy on education has emphasized that all children should be given equal opportunities regardless of imagined or real incapacities.

According to FRN (2013), the UBE programme shall be for a nine-year duration consisting of six years of primary education and three years of junior secondary education. The UBE shall be free and compulsory and also include adult and non-formal education programmes at primary and junior secondary school levels for the adult and out-of-school youths. The evolution of UBE scheme can be traced back to the Universal Primary Education (UPE) which was first introduced in the Western Region in 1955 and in the Eastern Region in 1957 respectively; but launched in 1976.UBE can be regarded as an off-shoot of the UPE scheme. However, the implementation of the UPE programme (that is, the process of moving the idea of UPE from concept to reality) was short lived as crises besieged it from the beginning. Inadequate funding, pupils' enrolment, poor quality teaching and supervision marked the UPE scheme. Conditions of schools were seriously and pathetically bad with other factors which led to the collapse of the UPE scheme. To this end, Major and Ominabo (2013) 
stated that the scheme was not properly planned and there was lack of popular will, political instability and the ability to sustain policies. They added that no reliable data was gathered and analyzed and no needs assessment was conducted before the implementation of the scheme. Teachers who were supposed to be the implementers of this policy on their own part did not understand the policy and were not carried along in the conceptualization and execution of the programme. All these among others made the programme to be unsuccessful. The scheme according to Ajayi and Adeyemi (2011) was then abandoned mid-way. This does not imply that the UPE did not offer something to its recipients in particular and Nigerian in general. The UPE programme was introduced again with a different concept and new name which eludes that UPE had something to offer. In order to have a more comprehensive universal compulsory formal education that will address the evaluation of education imbalance, boy dropout, illiteracy, perennial unemployment among others, the UBE was introduced.

The UBE programme was however launched by President Olusegun Obasanjo on the 30 ${ }^{\text {th }}$ of September, 1999 in Sokoto State. UBE is a policy reform measure of the FRN aimed at rectifying distortions in the basic education. The provision of UBE makes it mandatory to provide compulsory free universal primary education and smooth transition to three years of junior secondary education. This should translate to no entrance examination into junior secondary school. The inclusion of three years junior secondary education as part of the UBE programme reveals that primary education alone cannot sufficiently prepare the individual to survive in the ever-dynamic world of prevalent fast growing scientific and technological development which can give all round development of a person. The mission of the UBE is to serve as a prime energizer of the national movement for actualization of the Nigeria. UBE's vision working in concert with all stakeholders, thus mobilizing Nigeria's creative energies to ensure that education for all becomes responsibility of all. Their vision statements had it that at the end of the nine-year period of continuous education, every individual that passes through the system should acquire appropriate levels of literacy, numeracy, communication, manipulation of life skills and be employable, useful to him/herself and in the society at large by possessing relevant ethical, moral and civil values. The basic cardinal objective of the UBE is to promote equal access to free and compulsory nine years basic education from primary to junior secondary school (JSS) level which is also referred to as upper basic education level. It is also to guarantee a universal qualitative and functional education for every child of school age in Nigeria. The broad aim of the UBE is to lay solid foundation for life-long learning through the inculcation of appropriate learning-to-learn, selfawareness, citizenship and life skills FRN (2013). The main objective of the UBE is to eradicate illiteracy and ensure acquisition of functional skills. The Universal Basic Education Commission (UBEC) (2004) outlined the objectives of the UBE as:

- Acquiring the appropriate level of numeracy, life skills, communicative, manipulative, literacy, in addition to civic and security values required for setting the foundation for life-long learning.

- Cater via adequate mediums types of approaches that complement the promotion of UBE for children to learn, especially for those whose education was interrupted.

- $\quad$ Reduce severely drop out incidence from a formal school system via improved efficiency, quality and relevance.

- Providing UBE free for every Nigerian child who are of age

- Develop a high level of consciousness and strong motivation to education and promote such vigorously.

- It is within the nine years UBE programme that prevocational education or subjects are taught at the Upper basic education or junior secondary school level.

\section{Concept of Pre-vocational Education in Nigeria}

Pre-vocational education is functional and is geared towards general education purposes. Through the exposure to prevocational education, students advance: a wider understanding of the business and industrial process; individual interest and aptitudes; and desirable traits and attitudes such as pride in productive work, respect for authority and dignity for labour. These are attributes that can endear self-reliance. Prevocational subjects are offered at the junior secondary level of Education in Nigeria. Prevocational subjects include; Business Studies, Home Economics, Basic Technology, and Practical Agriculture. These subjects are foundation subjects in technology, which seek to immerse students in technology through exploration. Pre-vocational subjects offer students with orientation in producing and consuming through knowledge in evaluating, servicing, testing, producing and planning the type of industrial and consumer good (Uwameiye, 1993 in Oviawe, 2017). Exposing students to pre-vocational subjects ensure they develop a wider understanding of manufacturing processes and help them to explore their individual interest and aptitudes. Students may also develop desirable traits and attitudes, such as pride in productive work and respect for authority through such exposure (Uwameiyeand Onyewadume, 1999 in Oviawe, 2017). The viewpoint of prevocational state that graduates of upper basic education or the UBE programme need to be equipped with ability and familiarity with choices, career options and world of work. Pre-vocational topics are significantly vital to Nigeria's economy, this is due to the fact that it lays a solid framework for training future entrepreneurs, managers, accountants and technologists (AIuwomg, 2002 in Oviawe, 2015). FRN (2013) outlined the followings as the objectives of prevocational education in Nigeria;

- Introduction of students into the world of technology and choice of vocation at the end of junior secondary school and later in life; Acquisition of technical skills;

- Exposing students to career awareness by exploring usable options in the world of work; and

- Enabling youths to have an intelligent understanding of the increasing complexity of technology.

It is clear from the above, that the basic desire of government on prevocational education is to facilitate the process of economic and technological development of the country. The prevocational subjects are very unique among the subjects taught in Nigerian upper basic education level. Unlike other school subjects, students are required to work with equipment in the workshop; computer and typewriter in the typing pool; cutleries and utensils in the Home economics 
laboratory as well as farm tools and implements in the school demonstration farms. Prevocational education can be said to be an indispensable tool for achieving the objectives of the UBE programme in Nigeria.

Towards achieving the above laudable objectives of the UBE programme, the UBE act was introduced on the 26 of May, 2004. The act provides free and mandatory UBE. The enactment of this Act was followed by the establishment of the UBEC on the $7^{\text {th }}$ of October, 2004. The UBEC coordinates the implementation of the programme at the States and Local Government through the State Universal Basic Education Board (SUBEB) of each State and Local Government Education Authorities. The UBE Act made provision for the source of funding for implementing UBE: this is in form of $2 \%$ Federal Government Grant out of the consolidated revenue fund, from States and Local Governments. But for States to fully benefit from the Federal Government fund, it must contribute a minimum of $50 \%$ of the projects total cost. This ensures that all States are committed to this project. Regardless of these provisions, the UBE programme still has some impediments to implementing the programme. These impediments should be adequately addressed using prevocational education skills in order to have smooth implementation of the programme for quality assurance.

\section{Impediments to Implementing Universal Upper Basic Education Programme through Prevocational Education}

Impediments are hindrances or factors that tend to hinder effectiveness of a process. Eluwa (2011) defined hindrances as things that prevent the smooth running of a process. In this paper, impediments are factors that militate against the smooth implementation of the universal upper basic education programme. Implementation has been the bane of most achievable educational programmes in Nigeria. In spite of the laudable objectives of the UBE programme, it has not moved smoothly as some issues need to be addressed. These issues include:

\subsection{Adoption of Foreign Policies}

The implementations of education policies since the colonial era appear unrealistic. The development plans and policies of the Federal Government are anchored on foreign [policies that were not planned with the realities of the Nigerian economy. Adoption of foreign policies cannot guarantee effective implementation of education policies because the policies and plans are not based on the reality of the nation's economy.

\subsection{Financial Impediment}

The FRN (2013) in her nation policy on education stated that education is a capital-intensive social service which requires adequate financial provision from all tiers of government for successful implementation of educational programmes. Generally, the capacity to distribute funds for programs remain the biggest issue of any program. UBE programme is not an exception. The education subsector of the Nigerian economy has suffered gross under funding over the years. Aluede, Oviawe, Imhagbe and Ehiaguina (2019) reported that the Nigerian Government in recent years have failed to meet the recommendations of UNESCO which states that $26 \%$ be allocated to education irrespective of the government's claim of high budgetary allocation to the sector yearly. The record from budget allocation shows that government has not been able to allocate up to $26 \%$ of the annual budget to education which is the UNESCO's threshold. In 2017 for example, the total Federal allocation to education was just $6 \%$ of the annual budget. With this small amount allocated to education generally, it is very difficult to appropriate $2 \%$ to UBE only. Hence, this kind of funding is certainly affecting the implementation of government policy on education and UBE in particular.

Although the financing of UBE is not solely the responsibility of the Federal Government, the State and Local Governments who are supposed to allocate fund for the implementation of the UBE programme is not putting in enough. Due to corruption, the allocation of funds is insufficient and what is available is pilfered by workers in SUBEB offices over the nation (Labo-Popoola, Bello \& Atanda, 2019). For many years now, financial assistance has been received as grants from the Education Trust Fund (ETF) to sponsor UBE projects like building of classroom blocks for primary or junior secondary schools. But instead of doing exactly this, those that were awarded the execution of the project like building a new classroom block for a given school will just go there and renovate an existing classroom block in the school and put the remaining money in their private pocket. This is a typical example of embezzlement of the UBE fund which now increases the poor funding of UBE programme. This under-funding is an issue to the realization of the UBE objectives.

\subsection{Inadequate Planning}

The success of any educational system is hinged on proper planning and efficient administration. UNESCO (2000) asserted that there is lack of proper planning on the part of government. Adequate plans were not made in UBE to keep and muster demographic records that would enable Nigeria to estimate and determine the number of school-age children that will be in school for a good number of years. In Nigeria, planning has always been done based on inaccurate census data. Faulty census exercise has been among the factors responsible for improper planning. Almost all the census exercises carried out so far in Nigeria, either before independence or after, have been marred with massive irregularities (Alaba, 2010). The census figures may be inflated for political reasons, which in turn, make it impossible for educational planners to know and utilize accurate figures of school age children while planning for successful implementation of the UBE programme. The national population census that is supposed to provide reliable data for planning and implementation has always been politicized with its attendant wrong figures (Ayeni \& Adelabu, 2011). Planning with unreliable statistics will lead to poor projection as the facilities - classroom blocks, workshops, laboratories, libraries and teachers on ground will be inadequate for the number of persons in school. This makes them to merge learners in different levels in one class just to keep them under one roof. 


\subsection{Political Impediment}

The political hindrance on the success of educational planning arises from fusion of political and technical decisions and the nature of the political leadership. However, political considerations take precedence over technical ones. To this end, Adesina (2015) stated that it has become the practice to dismiss plans that are politically unacceptable in spite of their technical merit or to modify them to achieve the desire political results.

\subsection{Dearth of Infrastructure and Learning Facilities}

This is another issue facing the implementation of UBE programme. Severed schools are still overwhelmed with inadequate physical infrastructures and facilities for effective implementation of UBE programme. Ayeni and Adelabu (2011) posited that many schools do not have instructional materials like textbooks, workshop consumables, tools and equipments, laboratory facilities, audio-visual materials and where available, they are inadequate and obsolete. A number of schools UBE schools in Nigeria are characterized by limited resources, overcrowded classrooms and dilapidated buildings. Adepoju and Fabiyi (2007) in a demographic study on the existing national situation in the UBE sector indicated that $12 \%$ of UBE schools learners sit on the floor, $38 \%$ of classrooms have no ceilings, $87 \%$ of classrooms are overcrowded while $77 \%$ of these learners lack textbooks. The pertinent question here is "Can such UBE schools adequately fulfill the goals of the UBE?" These issues will have adverse effect of the students' academic outcome especially those in rural schools who have suffered neglect in terms of infrastructures and school facilities. In such cases, the teachers and learners hardly put in their best. The quality of learners UBE programme will produce in this kind of pitiable situation will be questionable. Thus, it is a big issue to the implementation of UBE.

\subsection{Improper Improvisation Programs to Overcome the Shortfalls of Instructional Aids}

As a result of poor funding of education in Nigeria, basic prevocational equipment and infrastructures that are crucial to the realization of its objections are not available (Oviawe, 2017). This challenge could have been reduced to its barest minimum if improvisation initiative is incorporated into prevocational education curriculum, to fabricate tools, equipments and other instructional materials locally to fill the vacuum created due to lack of funds to import such equipment.

\subsection{Inadequate Number of Qualified Teachers}

There is inadequate number of qualified teachers to adequately implement the UBE programme. To this end, Etuk, Ering and Ajake (2012) stated that there is shortage of capable teachers to handle the needs of UBE that arises from expanding on prior educational structure. This is evident as most primary schools lack qualified teachers especially in their specialist subject areas. Adenipekun (2006) in Ayeni and Adelabu (2011) posited that the issue of lack of teachers in UBE schools affects $85 \%$ of the States in Nigeria. Oviawe (2015) posited that teachers from other subjects and science subjects are uniquely poised to teach pre-vocational courses. This poses a problem to the implementation of UBE programme. This is because if most UBE schools in Nigeria lack qualified teachers, they will find it very difficult to adequately accommodate learners of junior secondary category who under the 9-3-4 system of education would become integral part of the UBE schools. The learners produced by unqualified and unskilled teachers are half-baked learners who graduate without being equipped with the needed educational basic skills that can match with that level of education the UBE programme is aimed at. It is a truism that no learner can raise above the quality of his/her teachers. Thus, the objective of having products of the UBE programme to possess literally and basic live skill will be defeated.

\subsection{Lack of Motivations in the Implementation of Prevocational Curriculum by Teachers}

Stenhouse in Oviawe (2017) opined that the absence of incentives is the cause for the teachers' rejection to take part in curriculum implementation. Incentives will influence and control teachers for the purpose of achieving educational goals. Teachers in Nigerian educational system is poorly motivated; this may be as a result of poor assimilation of the number of teachers required to implement the scheme and inaccurate financial evaluation and proper channels to disburse the funds required to finance the prevocational education programmes (Oviawe, 2017).

\subsection{Improper Project Monitoring and Supervision}

Improper project inspection, monitoring and supervision at all levels (Federal, State and Local Government) have been a major issue in the UBE programme. To this end, Okugbe (2009) asserted that the supervision is the life wire concerned with the efficiency and effectiveness of the UBE programme. Adequate supervision of any problem is the core of quality assurance of that programme. No human endeavour succeeds without proper and regular monitoring and assessment. Monitoring of UBE programme entails the continued evaluation of the implementation of education objectives at all levels of the system by SUBEB, LGEA and school heads (Eya \& Ani, 2012). The constraints to effective supervision and monitoring of UBE programme is attributed to lack of monitoring vehicles, inadequate office accommodation, inadequate funding, equipment and time factor (Okugbe, 2009). However, supervision exercise may be conducted but the staff involved in the monitoring and supervision may not submit their report to appropriate quarter that ought to handle the case. The issue of adequate documentation of supervision findings also hampers effective implementation of UBE programme.

\subsection{School Drop-Out Rate in Primary School Level}

One goal of UBE is to attain a hundred percent success to make persons of school age are enrolled in school. The realization of this goal is however seriously constraint by the drop-out-rate in UBE schools. Only $61.2 \%$ of the total 
population of school-age (below 14 years) was in school (Ogunjimi, Ajibola \& Akeh, 2009). The rate of dropouts indicates the access level of education by Nigerian children of school age which implies deception in the generalization of educations in Nigeria. UBE in Nigeria may be free on paper and in principle but a lot of funds are being extorted from the learners in the primary and junior secondary education levels which some parents may not be able to afford. The causes of schooldrop out involve but not limited to cost of schooling, illness, poverty, child labour, late entry into school/over aged persons, early marriage, and so on. Thus, the UBE programme is yet to attain education for all which stands as its primary objective.

\subsection{Low Level of ICT Utilization}

Most schools in Nigeria lack ICT equipment. Aromolaran (2014) in Oviawe (2017) reported the lack of ICT devices and facilities, that they are either unused or obsolete. Aromolaram (2017) further stated that students in this digital age employ various needs compared to previous learners. The curriculum should therefore be modified to take into consideration of current times. Majority of teachers and learners lack the ability to use computer and other electronic devices to access information from the internet. This brings about the inability of teachers to use electronic devices in teaching, learning and the organization of learning materials. Thus, computer and internet revolution are yet to be fully experienced in UBE programme. This is an answer to why the conventional method of teaching and learning still exists. Hence, there is no need upgrading the curriculum in line with global best practices as it will be challenging to its users. There may be cases in schools where ICT tools, equipment and facilities are available and personnel trained in its application. In this case, the constraint that affects its application is lack of electricity to power the ICT devices as electricity supply in Nigeria is very epileptic.

All these constraints are expected to be addressed for effective teaching and learning to take place towards achieving the objectives of Universal Basic Education programme. Achieving these will no doubt need proper planning, adequate funding, quality assurance measures and statistics.

\section{Optimized Measures for Implementing Universal Upper Basic Education Programme in Nigeria through Prevocational Education for Quality Assurance}

The paradigm shift in quality assurance in education reflect changes from old practices in inspecting, monitoring and assessing processes to provide new modes of assessment. This implies that input, process and output of the education system meets established standards and objectives to convey the improvements in learning and teaching. According to Alaba (2010), quality assurance is a mechanism used to evaluate the efficiency and appropriateness of teaching and learning experiences so as to ensure the delivery of high-quality education. It refers to the modalities for evolving, monitoring and re-appraising indices, benchmarks and good practices within an education system. The Nigerian Government realizing the need for quality assurance in her educational system emphasized in her national policy on education clearly the importance of basic education. To achieve this strong educational foundation, a combination of strategies or measures will yield best practices that will ensure quality education. Strategy is a process of planning interventions towards problems of threatening situations. Strategies are approaches designed to enhance methods of carrying out a task for best possible outcome. For proper implementation of the upper basic education in the Nigeria, education system needs the following:

\subsection{Adequate Funding through Increase in Government Budgetary Allocation}

The issue of funding of the UBE should be properly addressed by Government at all levels (Federal, State, and Local). Government being the key player in education should re-direct funds wantonly spent on passive and irrelevant issues like political parties' rallies to the funding of TVET in a bid to meeting the 26\% UNESCO recommendation benchmark. Whatever the allocation that is appropriated for education, salaries and allowances should be treated as separate components so that there can be clear cut differences in what the fund is for. The purpose the fund should be used for should be clearly spelt out (building classroom blocks, workshops, laboratories, instructional materials, and equipping the workshops/ laboratories, libraries, etc.) and non should be used for the other. Funds for workshops consumables, tools and equipment/laboratory materials must be used for that so that the workshops and laboratories can be adequately equipped for proper practical teachings and activities of prevocational education. With adequate funding, more classrooms, workshops, laboratories, studios, should be provided by the government and or community or even nongovernmental organizations.

Education is capital intensive, and government alone cannot single headedly fund it without a kind of collaboration in funding with multi-facet organizations. Collaboration is an arrangement between partners or parties to work together to achieve a common goal. Schools can partner with the private sector to build, equip and provided the required tools, equipment and facilities towards proper implementation of educational programmes to ensure that the overall goal of prevocational education (to provide learners the opportunity to acquire practical training to develop their skill) is actualized.

\subsection{Proper Planning}

There is need for proper planning of the UBE programme to ensure that educational resources are wisely planned and the objectives of the UBE in terms of provision are adequately achieved. The FRN should endeavour to have adequate and proper data about the UBE target group so as not to run into deficiencies when it comes to supply of both human and materials resources. The conduct of national census should be devoid of political undertone. Since prevocational education is scientific and technological base, and deals with facts and figures, the UBE planners should have known that they have to 
be exact in any figure they will give as prevocational education cannot accept inaccurate figures. For proper planning of the UBE programme, accurate data should be emphasized (vital registration system that can be used as a data bank).

\subsection{Provision of Infrastructures and Instructional Materials}

There should be adequate provision of infrastructures and instructional materials to enhance teaching and learning effectiveness. Afolayan (2010) asserted that the quality of education that learners receive bears direct relevance to the availability or lack of physical facilities and overall atmosphere in which learning takes place. The school facilities consist of all types of buildings for academic and non-academic activities, tools, equipment, areas for sport and games, landscape, farms and gardens, furniture, toilet facilities, electricity, ICT and other materials that play pivotal role in the actualization of the educational goals and objectives. Most UBE subjects, prevocational education subjects inclusive are practically oriented which most topics cannot be taught without instructional materials- tools, equipment and consumables for its practical activities. So, for the proper and successful implementation of the UBE programme, Government at all levels should see that all schools are duly supplied and equipped of their required materials. However, in situations where there are insufficient supplies of these instructional materials, prevocational education teachers can assist by skillfully improvising the materials using their scientific and technological knowledge and skills. By so doing exposing the learners to practical activities and the dream of the UBE may be realized through prevocational education. Oviawe (2015) posited that the government and the society owe the students the responsibility of providing an adequate environment necessary to promote learning of prevocational education in the curriculum. Prevocational education teachers and their students should maintain material supplied to them to ensure their longevity.

\subsection{Utilization of Improvised Instructional Materials}

Instructional resources or aids are materials, equipment and tools teachers employed by teachers in the teaching and learning procedure to make lessons practical, therefore minimizing thinking in abstracts with respect to students. The various aids consist of illustrations, pictures and real objects, the utilization of computers including others. Instructional resources make learning and teaching interesting and real, particularly students are involved in the production and utilization of such aids. In like manner, creativity is aroused and developed by students. Prevocational education teachers have the requisite training in the use of instructional materials and should use them in the implementation of prevocational education curriculum (Oviawe, 2017).

\subsection{Employment of Qualified and Competent Teachers}

Since education for all will bring about more enrolment in schools, which in turn will translate to provision of more teachers, Government at all levels should make adequate arrangement for proper training and retraining of teachers through seminars, workshops and conferences. Prevocational education teachers should also be motivated by giving them allowances and incentives to ensure dedication from them. Qualified prevocational teachers should teach school subjects in their areas of specialization thereby eliminating the idea of generalist teacher that teaches all the subjects. This will make good impact in achieving the objectives of prevocational education and the UBE in particular.

\subsection{Proper Monitoring and Supervision}

Supervision is the nucleus concerned with the effectiveness and efficiency of the UBE programme. Supervision of schools is the heart of quality assurance in education. The essence of monitoring and evaluation is to constantly ensure that the system has not deviated from the original plan (Okwori \& Ede, 2012). The monitoring and assessment of the UBE programme should be conducted regularly by all levels of Government. Thus, the Ministry of Education in partnership with SUBEB, even the LGEA and the inspectors of education should be empowered to execute this function. The impact of UBEC should be seen and felt at the State and Local Government levels. These bodies should supervise and monitor the school administration, teachers, learners and the utilization and handling of the resources made available to the schools to ensure that all duly works properly towards the successful implementation of the UBE. They should write their reports regularly when they visit the schools and submit same to the appropriate authorities.

\subsection{Exposing Learners' Work-Visit}

Visits can be arranged to facilitate visits to professionals, experts and technological companies for learners in order to compliment what is being taught in class (Oviawe, 2017). The study of Kelly (2011) in Oviawe (2017) postulated that work visits is a medium of reinforcing and expanding concepts that is taught in classroom (Kelly, 2011). Work visits provide opportunity for student's exposure via exploration to the workplace. Students get to learn firsthand how professionals and experts in the workplace work, qualifications required to enter the field. The student is helped in form of opinions on the requirements and nature of work towards intelligent career choices, and gives them to contribute to intelligent consumption of goods and services. Information obtained from work-visit provides awareness and enlightenment to students about their environment, which enables them make constructive and effective adjustments and motivates them to be serious with their studies (Uwameiye \& Onyewadume, 1999 in Oviawe, 2017).

\subsection{Reducing School Dropout Rate}

Towards achieving the objectives of the UBE, there is need to address the constraint of dropout so that retention of children in schools can be improved. Hence, the need to improve on regular attendance, make the curriculum activityoriented and operate a learner friendly environment. Although the UBE programme is said to be free in Nigeria, governments at all levels should completely abolish tuition and other forms of illegal fees or collections for the UBE 
programme so that more persons of school age can go to school. Actions need to be taken to strengthen the already existing poverty alleviation programmes so as to empower parents and guardians financially to enable them meet up with the basic financial demands of the basic education as it is not entirely free itself. Awareness should be created to parents on the importance of allowing their children and wards go to school. Tasks force can be put in place to arrest school age children found on the streets, markets or public places during school hours hawking or engage in other forms of business.

\subsection{Increased Level of ICT Adaptability}

The abysmally low level of ICT adoption in Nigerian schools is an issue that should be of concern to all stakeholders. The world is dynamic and is now a global village powered by ICT devices, facilities and tools. To this end, Major and Ominabo (2013) stated that it is critical that UBE schools reflect and use these devices. Inculcation of ICT to all UBE programmes is highly suggested. Upgrading of teacher's educational background and retraining them in impacting new methods and technologies of teaching using ICT is strongly suggested so as to transfer same to the learners. The prevocational teachers will assist here in several ways because most of them already have the outstanding performance in the use of ICT in executing education programmes.

\subsection{Provision of UBE Schools for Learners within Their Community}

UBE schools should be provided for all children within reasonable kilometer of walking distance, possibly within a kilometer of walking distance. This could be a measure for reducing dropout, thereby improving retention of learners in the UBE programme. Also, if the home is too far from the school, the learner gets exhausted and spent before getting to school, and this will adversely affect his/her concentration in the first few lessons for the day. In addition, community must be empowered to own and control schools. There is need to step up a community-based committee, comprising of seasoned educationist of high integrity, a representative of State UBE board (SUBEB) and the school head to serve as the governing council, to oversee the functioning of the UBE programme.

\subsection{Proper Record Keeping}

There is need for proper record keeping to ensure availability of accurate data on the system. The current effort of the Federal Ministry of Education in partnering with both UNESCO and UNDP on creation of educational data bank is highly commendable.

\section{Conclusion}

The UBE programme is one in which all stakeholders should embrace as it is a laudable education programme as its objectives are very promising. However, it is not free from constraints militating against its successful implementation which this paper has discussed. This paper also suggested quality assurance measures for enhancing the implementation of the UBE programme through prevocational education.

\section{References}

i. Adepoju, A. \&Fabiyi, A (2007). Universal Basic Education in Nigeria: Challenges and prospects. Retrieved on 10th October, 2018 from: $\quad$ http//: uaps2007princetonedu/download.asp?submission=70830

ii. Adesina, S. (2015). Growth without development: Nigeria's educational experience. Abeokuta: Educational Industries Ltd.

iii. Afolayan, E.A. (2010). An assessment of physical resources needed to achieve UBE objectives in Akoko North West Local Government Area of Ondo State. Education in rural Africa. Retrieved from: thestrikerst.blogspot.co.uk/2010/10/assessment-of-physical-resources-needed.html?m=1

iv. Ajayi, K. \&Adeyemi, M. (2011). Universal basic education policy implementation in facilities provision:Ogun State as a case study. International journal of new trends in education(IJCOSE), 1(3), 156-160.

v. Aluede, O., Oviawe, J.I., Imhangbe, O.S., \&Ehiaguina, S. (2019). Nation Building and Quality

vi. Higher Education in Nigeria: Implications for Teacher Education. Africa Education Review.

vii. Doi:org/10.1080/18146627.018.154995.

viii. Etuk, G.R.., Ering, S.O. \&Ajake, U.E. (2012). Nigeria's Universal Basic Education (UBE)

ix. Policy: A sociological analysis. American international journal of contemporary research 2(7), 179-183.

x. Eya, N.M. \& Ani, C.A. (2012). Prospect and challenges of Universal Basic Education in Nigeria: Implication for STM education. Proceeding of $53^{\text {rd }}$ Annual conference of STAN.

xi. Federal Republic of Nigeria (2013). National policy on education. Lagos: NERDC Press.

xii. Labo-Popoola, S.O., Bello, A.A. \&Atanda, F.A. (2009). Universal Basic Education in Nigeria: Challenges and way forward. Pakistan journal of social sciences 6(5), 252-259.

xiii. Major, N.B. \&Ominabo, J.N. (2013). Towards qualitative Universal Basic Education implementation in nigeria: The need for shifts in paradigms. International journal of educational foundations and management 1(2), 131-140. Retrieved on $10^{\text {th }}$ October, 2018 from: http://www.ijefm.com.

xiv. Ogunjimi, I.O, Ajibola, C.A. \&Akeh, L.U. (2009). www.sist.sciendev.net/IMG/Biblio

xv. Okugbe, G.E. (2009). The challenges affecting the implementation of the Universal Basic Education in Delta State, Nigeria. Kamla-Raj journal of social science, 29 93), 183-187.

xvi. Okwori, A. \& Ede, S. (2012). Management issues in education. Makurdi: Aboki Publishers. 
xvii. Oviawe, J. I. (2015). Sustaining students' interest in Prevocational Education: a strategy for fostering enrolment intoTechnical colleges in Nigeria. International Journal Academic Research in Progressive Education and Development 4 (3), 1-11.

xviii. Oviawe, J.I. (2017). Strategies for enhancing the implementation of prevocational education curriculum Nigeria. International Journal of Secondary Education. 5 (4), 42-46.

xix. Universal Basic Education Commission (UBEC), (2004). Ubeconline.com/aboutubeco.html

xx. UNESCO, (2000). Education for All. www.enesco.org//educationforall 